\title{
TRANSNASAL ESOPHAGOSCOPY EXAMINATION IN OUTPATIENT UNIT, DEPARTMENT OF OTORHINOLARYNGOLOGY HEAD AND NECK SURGERY, DR. SOETOMO HOSPITAL, SURABAYA
}

\section{Rizka Fathoni Perdana}

Department of Otorhinolaryngology Head and Neck Surgery, Faculty of Medicine, Universitas Airlangga/Dr. Soetomo Hospital, Surabaya, Indonesia

\section{ABSTRACT}

Esophagoscopy is the standard examination standard for evaluation, diagnosis, screening and surveillance of esophageal diseases. Although it is often done, esophagoscopy costs a lot, is inconvenient, and risks complications, including cardiopulmonary complications because patients usually require routine sedation in the implementation of conventional esophagoscopic procedures. The purpose of this study is to get an overview of the results of the implementation of transnasal esophagoscopy in Department of Otorhinolaryngology Head and Neck Surgery, Division of Broncho-oesophagology, Dr. Soetomo Hospital, Surabaya, between 1 September 2012 and 30 April 2015. This study was a retrospective descriptive study with a population of all patients undergoing esophagoscopic examinations during this period. Data is taken from medical records of new patients undergoing transnasal esophagoscopy. Inclusion criteria were all patients who had been tested for transnasal esophagoscopy, and exclusion criteria were incomplete medical record data. There were 35 patients who underwent transnasal esophagoscopy examination at Department of Otorhinolaryngology Head and Neck Surgery, Division of Bronchooesophagology, Dr. Soetomo Hospital, Surabaya during the study period. The mean of patients who participated in the study was $54.17 \pm 14.02 .23$ male patients $(63.89 \%)$, while 12 female patients or $34.11 \%$. Indications of dysfagi are found in all age groups, most in the age group 51-70 years. Metastases in head and neck malignancies are found in the age group 31 - 50 years and 51 - 70 years. Indications for heartburn are found in the age group 21-50 years and 51-70 years. In conclusion, the results of transnasal esophagoscopic examination showed that most patients had a normal picture (60\%) and a positive picture with an esophageal abnormality of $40 \%$. The most common features are lesions in the mucosal esophagus lumen, scar, masses and stenosis.

Keywords: Transnasal, esophagoscopy; outpatient

\section{ABSTRAK}

Esofagoskopi merupakan standar baku pemeriksaan untuk evaluasi, diagnosis, skrining dan surveilans penyakit esofagus. Meskipun sering dilakukan, esofagoskopi membutuhkan biaya yang tidak sedikit, tidak nyaman, dan berisiko komplikasi, antara lain komplikasi kardiopulmonal karena pasien biasanya memerlukan sedasi rutin pada pelaksanaan prosedur esofagoskopi konvensional. Tujuan penelitian ini adalah mendapatkan gambaran hasil pelaksanaan esofagoskopi transnasal di Divisi Bronko-esofagologi, URJ THT-KL, RSUD Dr. Soetomo, Surabaya, Indonesia, antara 1 September 2012 sampai 30 April 2015. Penelitian ini merupakan penelitian deskriptif retrospektif dengan populasi seluruh penderita yang menjalani pemeriksaan esofagoskopi pada periode tersebut. Data diambil dari rekam medik pasien baru yang menjalani pemeriksaan esofagoskopi transnasal. Kriteria inklusi adalah seluruh penderita yang telah dilakukan pemeriksaan esofagoskopi transnasal, dan kriteria eksklusi adalah data rekam medik tidak lengkap. Didapatkan sebanyak 35 penderita yang menjalani pemeriksaan esofagoskopi transnasal di URJ THT-KL, RSUD Dr. Soetomo, Divisi Endoskopi Bronko-Esofagologi selama periode penelitian tersebut. Rerata penderita yang ikut dalam penelitian adalah 54,17 $\pm 14,02$. Pasien laki-laki sebanyak 23 orang (63,89\%), sedangkan pasien perempuan 12 orang atau $34,11 \%$. Indikasi disfagi didapatkan pada semua kelompok umur, terbanyak pada kelompok umur 51 - 70 tahun. Metastasis pada keganasan kepala leher didapatkan pada kelompok umur 31 - 50 tahun dan 51 - 70 tahun. Indikasi karena heartburn didapatkan pada kelompok umur 21 - 50 tahun dan 51 - 70 tahun. Sebagai simpulan, hasil pemeriksaan esofagoskopi transnasal menunjukkan sebagian besar pasien memiliki gambaran normal (60\%) dan gambaran positif dengan kelainan esofagus sebanyak 40\%. Gambaran terbanyak adalah lesi pada mukosa lumen esofagus, sikatrik, massa dan stenosis.

Kata kunci: Transnasal, esofagoskopi; rawat jalan

Correspondence: Rizka Fathoni Perdana, Department of Otorhinolaryngology Head and Neck Surgery, Faculty of Medicine, Universitas Airlangga/Dr. Soetomo Hospital, Surabaya, Indonesia. E-mail: rizka-f-p@fk.unair.ac.id

pISSN:2355-8393 • eISSN: 2599-056x • doi: 10.20473/fmi.v56i1.18455

- Fol Med Indones. 2020;56:75-81 • Received 10 May $2017 \bullet$ Accepted 16 Nov 2017

- Open access under CC-BY-NC-SA license • Available at https://e-journal.unair.ac.id/FMI/ 


\section{INTRODUCTION}

Esophagoscopy is the standard examination standard for evaluating, diagnosing, screening and monitoring oesophageal diseases. Esophagoscopy is a procedure that has often been done, but requires no small cost, discomfort when performed and has the risk of complications (Aedo et al 2014).

Several non-invasive and invasive methods have been proposed as conventional esophagoscopic alternatives for the diagnosis of esophageal disease lately. Patients generally require routine sedation in the implementation of conventional esophagoscopic procedures, this presents a risk of cardiopulmonary complications (Belafsky et al 2001).

Esophagoscopic procedures accompanied by sedation in patients require good care and monitoring both before and after the procedure. Patients may not be able to start routine activities immediately after the procedure and amnesia can occur after the examination procedure (Chheda et al 2010).

Esophagoscopy can be done without sedation, for example flexible esophagoscopy with small caliber which is done transnasally and is called transnasal esophagoscopy. The advantage offered is a complete examination of the upper digestive tract in a short time without the provision of sedation (Sabirin et al 2015).

Small caliber transnasal oesophagoscopy without sedation provides efficiency and accurate endoscopic assessment of the esophagus, with a lower risk than procedures with sedation and can be used as a method for screening oesophageal disease in primary health centers (Kuhn et al 2013).

Examination using transnasal esophagoscopy in the Outpatient Unit, Department of Otorhinolaryngology Head and Neck Surgery, Division of Bronchooesophagology, Dr. Soetomo Hospital, Surabaya, was the first time in 2012. Since the last 3 years the patient's characteristics and variations in transnasal indications have been obtained. This study aims to get an overview of the results of the implementation of transnasal esophagoscopy at Outpatient Unit, Department of Otorhinolaryngology Head and Neck Surgery, Division of Broncho-oesophagology, Dr. Soetomo Hospital, Surabaya, from 1 September 2012 to 30 April 2015.

\section{MATERIALS AND METHODS}

This was a retrospective descriptive study conducted at Department of Otorhinolaryngology Head and Neck
Surgery, Division of Broncho-oesophagology, Dr. Soetomo Hospital, Surabaya. The limited population of this study was all patients who underwent transnasal esophagoscopy at Department of Otorhinolaryngology Head and Neck Surgery, Division of Bronchooesophagology, Dr. Soetomo Hospital, Surabaya from September 1, 2012 to April 30, 2015. The research sample was data that met the inclusion and exclusion criteria.

Transnasal oesophagoscopy was performed using topical anesthesia without sedation. Topical anesthesia was given to the nasal cavity using $2 \%$ lidocaineephedrine cotton to get the vasoconstrictive effect and reduce pain, then two xylocain $10 \%$ sprays sprayed on the oropharynx and hypopharynx to reduce the gag reflex and reduce pain. The procedure was in accordance with Akil's study (2014). Flexible esophagoscope with a $5.8 \mathrm{~mm}$ diameter scope using the Olympus Evis Excera II camera system. The device has a system of water flushing and air insuflation, as well as suction through the working channel available.

Data taken from the medical records of new patients to undergo transnasal esophagoscopy examination period 1 September 2012 to 30 April 2015 in the outpatient unit of THT-KL RSUD Dr. Soetomo Surabaya. Inclusion criteria were all patients who had undergone a transnasal esophagoscopy examination in that period. Criteria for exclusion of incomplete medical record data for analysis. Sources of patient data were taken from the broncho-esophagological endoscopy activity book register and the transnasal esophagoscopy report book from September 1, 2012 to April 30, 2015. The data was then tabulated and the descriptive component was calculated and presented in tables and diagrams.

\section{RESULTS}

There were 35 patients who underwent transnasal esophagoscopy examination at Department of Otorhinolaryngology Head and Neck Surgery, Division of Broncho-oesophagology, Dr. Soetomo Hospital, Surabaya during the study period. All patients were included in the study because they met the inclusion and exclusion criteria. Descriptive indicators used include mean \pm SD (standard deviation) or average values \pm standard deviation, and range values (minimum maximum values).

\section{Age characteristics of patients}

The mean of patients who participated in the study was $54.17 \pm 14.02$. The youngest age in this study was 15 and the oldest age was 74 years. The number of patients 
in the age group of less than 20 years is two people $(5.71 \%)$, while the number of patients in the age range of 21 to 50 years is 7 people $(20 \%)$. The age range between 51 years and distribution of patients according to age group with the highest number of patients is in the range of 51 to 70 years with the number of 24 patients $(68.58 \%)$. The number of patients in the age group of more than 70 years was 2 patients or 6.71 percent (Table 1).

Table 1. Distribution of age groups

\begin{tabular}{ccc}
\hline Age group (years) & Total & Percentage (\%) \\
\hline$<20$ & 2 & 5.71 \\
$21-50$ & 7 & 20.00 \\
$51-70$ & 24 & 68.58 \\
$>70$ & 2 & 5.71 \\
\hline Total & 35 & 100 \\
\hline
\end{tabular}

\section{Sex}

The sex distribution in this study was male with 23 patients $(63.89 \%)$, while female patients were 12 patients or $34.11 \%$ (Fig. 1).

\section{Indication}

Patients were grouped based on indications of transnasal esophagoscopy. Indications for examination were grouped including dysphagia, evaluation of metastasis in head neck, heartburn, and hoarseness. Dysfagi as an indication of transnasal esophagoscopy was found in 25 patients $(71.42 \%)$. Screening for esophageal metastases for head and neck malignancies was found in as many as 8 patients $(22.85 \%)$. Two patients $(5.71 \%)$ had an indication of heartburn surgery so a transnasal esophagoscopy was performed (Table 2).

The diagram below (Fig. 2) displays the distribution of transnasal esophagoscopic indications based on the age group of the patient. Dysfagi indications are found in all age groups and most in the age group 51-70 years. Evaluation of metastasis in head and neck malignancies is found in the age group 31-50 years and 51-70 years. Indications for hearburn are found in the age group 2150 years and $51-70$ years.

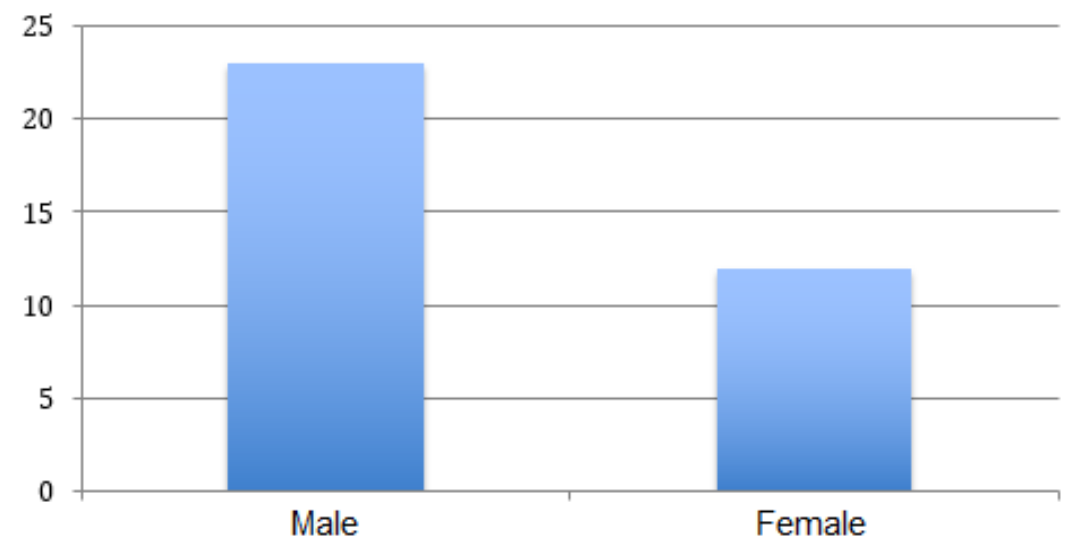

Fig. 1. Sex distribution.

Table 2. Indications of inspection

\begin{tabular}{ccc}
\hline Indication & Total & Percentage (\%) \\
\hline Dysphagia & 25 & 71.42 \\
$\begin{array}{c}\text { Evaluation of metastasis } \\
\text { in head and neck } \\
\text { malignancies } \\
\text { Heartburn }\end{array}$ & 8 & 22.85 \\
\hline Total & 2 & \\
\hline & 35 & 5.71 \\
\hline
\end{tabular}




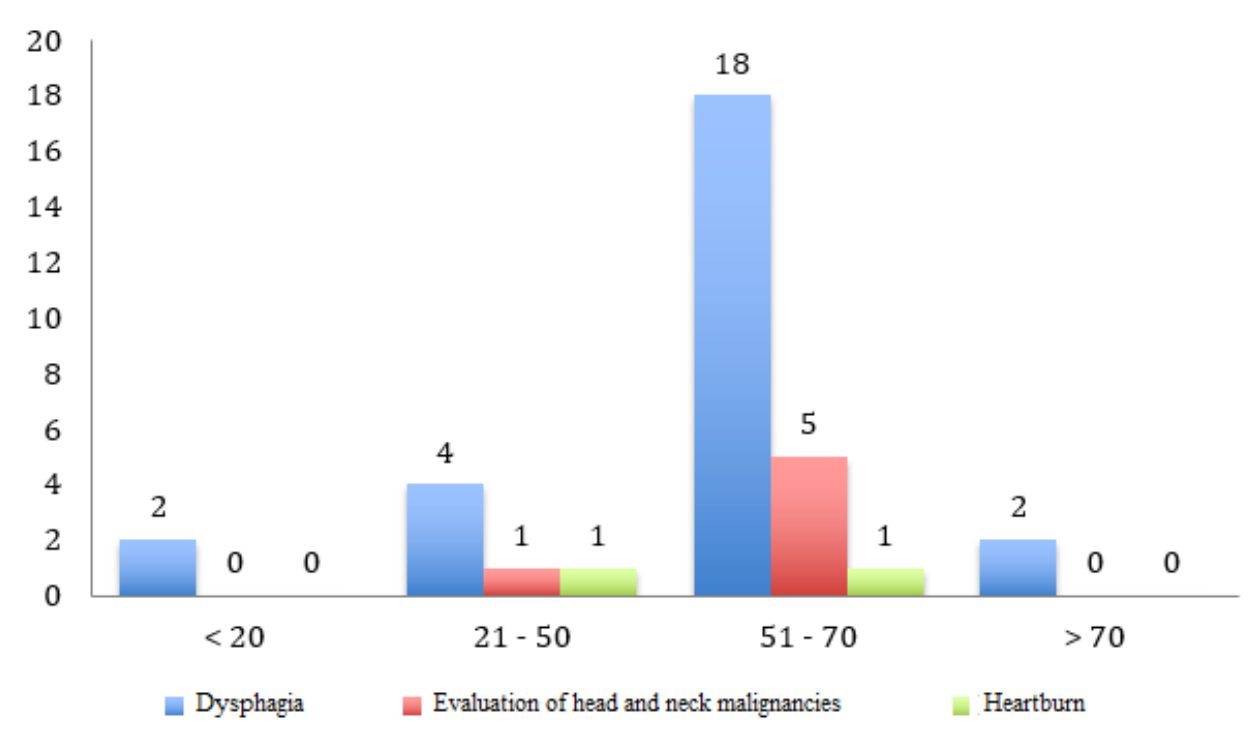

Fig. 2. Distribution diagram of inspection indications by age group

Table 3. Examination results

\begin{tabular}{lcc}
\hline \multicolumn{1}{c}{ Examination results } & Total & Percentage (\%) \\
\hline Mass & 2 & 5.71 \\
Mucosal lesions & 7 & 20 \\
Scar & 3 & 8.57 \\
Stenosis & 2 & 5.71 \\
\hline Total & 14 & 100 \\
\hline
\end{tabular}

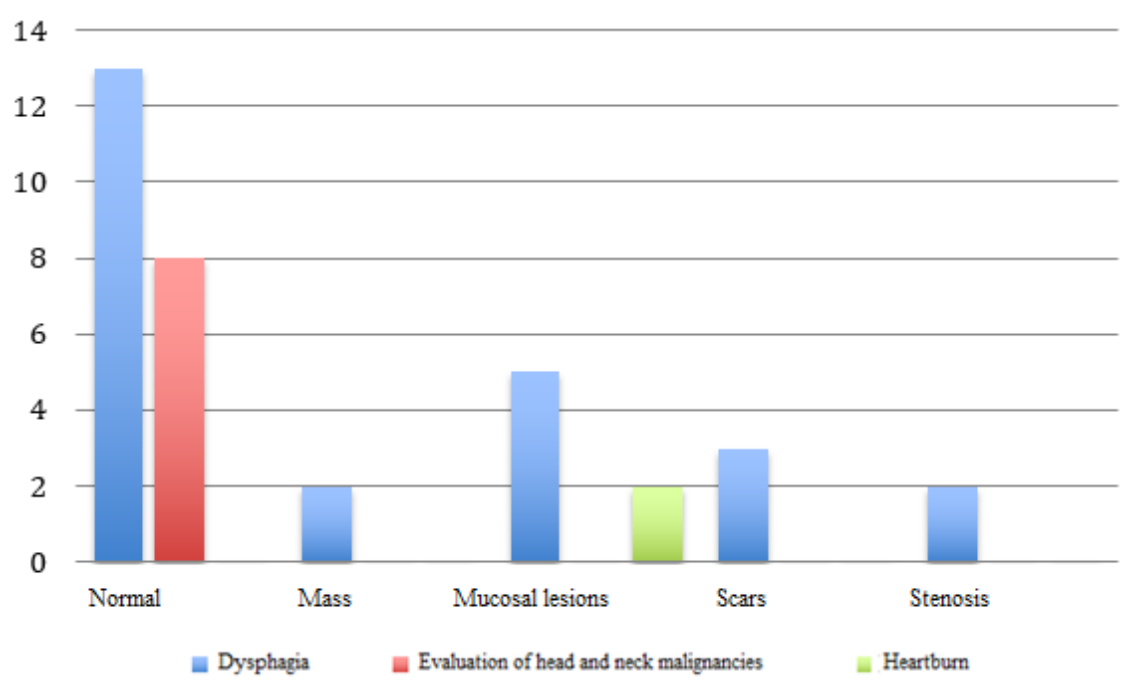

Fig. 3. Diagram of the results of transnasal esophagoscopy. 


\section{Examination results}

Table 3 shows the results obtained during the examination. Obtained normal esophageal results with $21(60 \%)$ patients out of 35 patients. Positive results were obtained with the number of mucosal lesions of seven $(20 \%)$ patients. Mass was obtained by $3(5.71 \%)$, then scar was obtained by three patients $(8.57 \%)$ and stenosis by 2 patients $(5.71 \%)$. Diagram of the results of the transnasal esophagoscopy examination is categorized based on the indications of the examination at the time the patient arrived at the outpatient unit of Division of Broncho-oesophagology, Dr. Soetomo Hospital, Surabaya (Fig. 3).

Normal examination results obtained by 13 people (52\%) of 25 patients with indications of dysphagia and 8 people $(100 \%)$ of 8 patients with an evaluation of the head neck malignancy. Mass was obtained in 2 people (8\%) of 25 dysphagia patients. Mucosal lesions were received in 5 people (20\%) of 25 dysphagia patients and 2 people (100\%) of 2 heartburn patients. Scars were found in 3 people (12\%) and stenosis was found in 2 people (8\%) of 25 dysphagia patients.

\section{DISCUSSION}

This was a retrospective descriptive study because it displays a descriptive picture of the data collected. Data were from the past written in medical records at Department of Otorhinolaryngology Head and Neck Surgery. The population in this study were patients who underwent transnasal esophagoscopic examinations at Department of Otorhinolaryngology Head and Neck Surgery, Division of Broncho-oesophagology, Dr. Soetomo Hospital, Surabaya. The population of this study was limited by place and time. The entire population was selected as a research sample. Thirtyfive samples were found that met the research criteria, then tabulated and calculated for descriptive analysis.

\section{Age characteristics of patients}

The mean age of patients in this study was $54.17 \pm$ 14.02 with a range of 15-74 years. Research by Co S, et al (2001) shows the average age of 57 years with a range of 15-87 years. This shows that the mean and age range of this study were similar to studies originating from Canada.

Characteristics of patients of this study are dominated by the age group of 51 to 70 years. The smallest number is in the age group under 20 years and above 70 years. This shows that when dysfagi is found in many patients with that age range. Described by Sura et al (2012), dysphagia is one of the problems with swallowing that is commonly found in older people. Dysphagia can be an anatomic or physiological deficit in the mouth, pharynx, larynx and esophagus. The process of swallowing changes with age. Increasing age will cause a decrease in the quality and effectiveness of the ingestion process. Dysphagia is often found in patients with age above 60 years. Thus, the average age of patients in this study is similar with the report by Sura et al (2012), which is a number of 26 patients (74.29\%) of all samples.

Another reason for the age range of most of the study samples at 51-70 years is due to the fact that this range was mostly dominated by patients of head and neck malignancies who undergo screening using ETN. Patients with head and neck malignancies who will undergo surgery require screening for an expansion of malignancy in the esophagus.

\section{Sex}

Complaints of dysfagi can be found in men and women with almost the same ratio. This study found more male results than women. This can be caused by the dominance of the occurrence of head and neck malignancies in this study. This causes the study sample to be dominated by men compared to women. This is different from Chung et al (2014) who reported a number of male and female compardoisons with a ratio of 1: 1 . In that study, there were not many patients of head and neck malignancies as a study sample so that the ratio of men and women was balanced.

\section{Indication}

The most frequently indicated indication was dysphagia $(71.42 \%)$, then heartburn complaints ranked third $(5.71 \%)$. Metastatic screening in head and neck malignancies ranks second most. Most malignancy screening is in the age group of 51 to 70 years. This is caused by the distribution of laryngeal malignancy patients most in this group, although it is also found in the age group of 21 to 50 years with a total of $2.86 \%$.

Heartburn is one of the specific symptoms of dysphagia with abnormalities in the form of relfux esophagitis (Wolf 1990). The number of incidents or prevalence of relux with hearburn complaints does not yet exist in Indonesia. relfuks as part of reflux esophagitis can also be accompanied by odinophagi. This is caused by inflammation of the esophagus and in the long term can cause narrowing of the esophagus (Wolf 1990). Oesophageal reflux will also be associated with oesophageal Barrett and esophageal adenocarcinoma. 
Chung et al (2014) reported that the evaluation of pharyngeal laryngeal reflux disease occupies the highest number and dysphagia was found in only 9 of 137 patients $(6 \%)$. This is in contrast with this research. The difference can be caused by the habit of drinking alcohol in Korea, so in that country the incidence of reflux disease is very high. It was also reported that the detection of the possibility of metachronous events in malignancies or screening for malignancies could be done using ETN. Cho et al (2008) reported indications of ETN including dyspepsia and heartburn of $49.8 \%$ and $22.5 \%$, respectively, then dysphagia of $4.3 \%$. The report is similar to Chung et al's (2014) study. Cho's research came from Canada, which has a typical resemblance to Chung's from Korea in the form of complaints of reflux disease.

Transnasal esophagoscopy can also be used as an evaluation tool for head and neck malignancies based on the American Society for Gastrointestinal Endoscopy (ASGE) quoted from Postma et al (2007). Panendoscopy is the evaluation standard but has a high risk in patients with comorbid because it requires general anesthesia. The role of ETN is very high for examining aerodigestive tracts without the risk of using general anesthesia. The American bronchooesophagology association states that ETNs carried out in outpatients have the same advantages as panendoscopy in the operating room.

Postma et al (2005) reported an indication of head and neck malignancy screening using ETN of 7\%, while Chung et al (2014) reported an amount of $12 \%$. The report is slightly different from this report which received $22.85 \%$. This amount is dominated by patients with laryngeal malignancy who will undergo total laryngectomy.

The most indication of dysfagi is in the age range of 51 to 70 years and in the range of 21 to 50 years. These results are consistent with the explanation by Sura et al (2012). Functional dysfagi (difficult to swallow) is closely related to aging, so it is called age-related disease. Sura et al (2012) suggested that dysphagia in old age occurs in $70 \%$ of people aged over 65 years. The incidence of dysphagia is also high in stroke patients, ranging from 30 to $65 \%$ in the United States.
The results of this study are in accordance with the literature.

\section{Examination results}

Abnormalities in the esophagus were found in $40 \%$ of all patients examined by ETN. Most abnormalities are lesions of the esophageal mucosa, followed by scars, stenosis and tumors. Indications for evaluation of head and neck malignancies also contribute to normal ETN examination results. The percentage of positive results in this study is almost similar to some ETN examination reports.

The $40 \%$ positive findings are also in accordance with reports from several researchers. The indications for ETN inspection are in accordance with the references originating from ASGE. Indications of ETN based on the American Society for Gastrointestinal Endoscopy (ASGE) and the American College of Gastroenterology (ACG) are divided into two main criteria, namely procedures on the esophagus and extraesophagus.

Chung et al (2014) conducted an ETN examination in Korea and reported positive findings obtained by $38.7 \%$ of the 137 patients studied. Reports by Belafsky et al (2001) in the United States showed positive findings on ETN examination in $44 \%$ of 96 patients examined. Cho et al (2008) reported slightly different results from this study; of the 237 studied, normal results in esophageal examination were $38 \%$ or positive abnormalities were $62 \%$.

Fifty-two percent of normal results obtained from patients with dysfagi who underwent ETN examination. Indications for dysphagia can be derived from the main complaint, and supported by radiological features that show an abnormality. Research by Dean et al (1996) reported that there is a strong relationship between the features found endoscopically transnasal esophagoscopy (sensitivity $89 \%$, specificity 97\%) and conventional esophagos-gastroduodenoscopy.10 This suggests that complaints of dysphagia in this study are still insensitive to sensitivity. to suspect an abnormality in the esophagus.

Table 4. Diagnostic indications for esophagoscopy

\begin{tabular}{ll}
\hline Relative indication & Absolute indication \\
\hline Dysphagia & Dilated stricture \\
Odinophagia & Move the feeding tube \\
Weight loss & \\
Anorexia & \\
Evaluation after caustic ingestion & \\
Reflux symptoms $>5$ years & \\
Evaluation and extraction of foreign matter & \\
\hline
\end{tabular}


Research conducted by Andrus et al (2005) has similarities with this study. The sample size was 30 patients with complaints of dysphagia, reflux symptoms, malignancy. Of the complaints found, $43 \%$ of patients had a positive picture showing an abnormality in the esophagus, where in this study, it was also obtained a positive picture with an esophageal abnormality as much as $40 \%$ and a normal picture as much as $60 \%$.

Complaints of dysphagia that arise can be due to extraesophageal processes, for example complaints of dysphagia can be caused by systemic processes due to hormonal namely hypothyroidism and diabetes mellitus but it can also be due to amyloidosis. In this patient esophageal dysfunction occurs, esophageal peristalsis, disruption in the relaxation phase of the lower esophageal sphincter or decrease in pressure of the lower esophageal sphincter, so besides endoscopy also requires other modalities to confirm abnormalities that occur, e.g., esophagogram and esophageal manometry.

Abnormalities found in patients with dysphagia are dominated by mucosal lesions by $20 \%$, then scars by $12 \%$, and mass and stenosis by $8 \%$. The mass will cause complaints of progressive dysphagia. Stenosis and scars cause dysphagia which is more stable or progressive but slowly. Abnormalities in the form of mass, stenosis or scars often appear on radiological features.

The results of this research examination are different from other publications. Chung et al (2014) got the most results of examinations is esophagitis. This is consistent with the most indications of suspicion of gastroesophageal reflux. This is caused by not many patients who are examined with suspected reflux or with heartburn complaints.

\section{CONCLUSION}

The results of ETN examination in this study mostly obtained a normal picture $(60 \%)$ and a positive picture with an esophageal abnormality of $40 \%$. The most common feature is the presence of lesions in the mucosal lumen of the esophagus and is followed by scars, masses and stenosis.

\section{REFERENCES}

Aedo M, Gonzalez M, Daza A, Troche J (2014). Accuracy of transnasal endoscopy with a disposable esophagoscope compared to conventional endoscopy. World J of gastrointestinal endoscopy 6,128-36

Akil M (2014). Evaluasi proses menelan dengan pemeriksaan fiberoptic evaluation of swallowing, esofagoskopi kaku dan esofagoskopi transnasal. In:
Juniati S. Penatalaksanaan terkini pada disfagia. Surabaya, KODI EBE Perhati-KL, p 32-50

Andrus JG, Dolan RW, Anderson TD (2005). Transnasal esophagoscopy: a high-yield diagnostic tool. Laryngoscope 115, 993-6

Belafsky P, Postma G, Daniel E, Koufman J. Transnasal esophagoscopy. American academy of otolaryngology head and neck surgery foundation. 2001. Available at http://transnasalesophagoscopy.com/wp-content/uploads/2011/03/TNE-Paper-20011.pdf. Accessed June $15,2015$.

Cho S, Swan K, Arya N, Cirocco M, Kandel G, Kortan P, Marcon N (2008). Unsedated transnasal endoscopy: a Canadian experienxe in daily practice. Can J Gastroenterology 22, 243-6

Chheda N, Postma G (2010). Transnasal esophagoscopy. In: Flint P, Haughey B, Lund V, Niparko J, Richardson M, Robbins K, Thomas J, eds. Cummings otolaryngology head and neck surgery. 5th ed. Philadelphia, Mosby inc, p 981-5

Chung E, Rho Y, Jung K, Kim J, Lee S (2014). The role of transnasal esophagoscopy in ENT office: a prospective, multicenter study in Korea. Korean society of otorhinolaryngology head and neck surgery. 2014. Available at http://www.ncbi.nlm.nih.gov/pubmed/24917909. Accessed July 13, 2015

Dean R, Dua K, Massey B, Berger W, Hogan WJ, Shaker R (1996). A comparative study of unsedated trasnnasal esophagogastroduodenoscopy and conventional EGD. Gastrointest Endosc 44, 422-4

Kuhn M, Amin M (2013). Transnasal and rigid esophagoscopy. In: Kountakis S. Encyclopedia of otolaryngology head and neck surgery. Heidelberg, Springer-Verlag Berlin Heidelberg, p 2865-6

Postma G, Seybt M, Rees C (2009). Esophagology. In: Snow J, Wackym P, eds. Ballenger's otorhinolaryngology head and neck surgery. 17th ed. New York, BC Decker inc, p 975-82

Sabirin J, Rahman M, Rajan P (2013). Changing trends in oesophageal endoscopy: a systematic review of transnasal oesophagoscopy. Hindawi publishing corporation. Available at http://www.hindawi.com/ journals/isrn/2013/586973/ . Accessed July 20, 2015

Sura L, Madhavan A, Carnaby G, Crary MA (2012). Dysphagia in the eldery: management and nutritional considerations. Clinical Intervention in Aging 2012, 287-298

Wolf DC (1990). Dysphagia. In: Walker HK, Hall WD, Hurst JW, editors. Clinical Methods: The History, Physical, and Laboratory Examinations. 3rd ed. Boston, Butterworths. Available at https://www.ncbi. nlm.nih.gov/books/NBK408 